\title{
OXIDATIVE STRESS SUPPRESSION CONTRIBUTES TO ANTISEIZURE ACTION OF AXITINIB AND RAPAMYCIN IN PENTYLENETETRAZOL-INDUCED KINDLING
}

\author{
O. B. POSHYVAK ${ }^{\boxplus}$, O. R. PINYAZHKO ${ }^{1,2}$, L. S. GODLEVSKY ${ }^{3}$ \\ ${ }^{1}$ Pharmacology Department, Danylo Halytsky Lviv National Medical University, Lviv, Ukraine; \\ ${ }^{2}$ Department of Civilization Diseases and Regenerative Medicine, WSIiZ, Rzeszow, Poland; \\ ${ }^{3}$ Department of Biophysics, Informatics and Medical Devices, \\ Odesa National Medical University, Odesa, Ukraine; \\ 凶e-mail: olesya.poshyvak@gmail.com
}

Received: 29 January 2021; Accepted: 23 April 2021

\begin{abstract}
Rapamycin and axitinib block different kinases in signaling pathways such as PI3K-Akt-mTOR and $B D N F-T r k B$, respectively. Both have antiseizure and antioxidative actions, which justify studying the combined effects of these drugs upon seizures and oxidative stress in the chronic model of epilepsy. The investigation aimed to look for the combined effect of rapamycin and axitinib upon pentylenetetrazol (PTZ)-kindled seizures and oxidative stress. Experiments were performed on 300 two-to four-month-old Wistar male rats, which had been kindled daily with PTZ (35.0 mg/kg, i.p.). Malondialdehyde (MDA) level, superoxide dismutase (SOD) activity, and glutathione (GSH) level were determined in brain tissues of kindled rats before and after the treatment. The analysis of antiseizure and antioxidative actions was performed using $E D_{50}$ of rapamycin and axitinib, with their combined administration using graded dosages of $E D_{50}$ of each drug. The median effective dose $\left(E D_{50}\right)$ for rapamycin and axitinib was 0.93 and $4.97 \mathrm{mg} / \mathrm{kg}$, respectively. ED $D_{50}$ of rapamycin when combined with axitinib $(2.0 \mathrm{mg} / \mathrm{kg})$ was $0.60 \mathrm{mg} / \mathrm{kg}$, which was reduced by $35.6 \%$ when compared with the $E D_{50}$ administered alone $(P<0.05)$. The MDA level increased from $152.9 \pm 24.8$ to $388.3 \pm 49.2 \mathrm{nmol} / \mathrm{mg}$ of protein $(P<0.05)$, while SOD activity reduced from $11.14 \pm 2.33$ to $3.54 \pm 1.08 \mathrm{IU} / \mathrm{mg}$ of protein $(P<0.05)$ in brain tissues of the kindled rats. Combined treatment with rapamycin $(0.56 \mathrm{mg} / \mathrm{kg}$, i.p.) and axitinib $(2.0 \mathrm{mg} /$ $\mathrm{kg}$, i.p.) resulted in a significant rise in SOD activity $(11.09 \pm 1.86 \mathrm{IU} / \mathrm{mg})$ and $\mathrm{GSH}$ level $(7.32 \pm 1.34 \mu \mathrm{g} / \mathrm{mg})$ when compared with the kindled rats $(P<0.05)$. Combined axitinib and rapamycin therapy have an antiepileptic and antioxidative effect on PTZ-kindled seizures.
\end{abstract}

Keywo rds: seizures, pentylenetetrazol kindling, oxidative stress, axitinib, rapamycin.

\section{Introduction}

Pharmacologically resistant forms of epilepsy, which are observed in one-third of patients, are a great challenge for antiepileptic treatment [1].

The antiepileptic effect of axitinib on the pentylenetetrazol (PTZ)-induced kindling rat model was shown earlier [2], and suppression of tyrosine kinase type B was identified as a new target [3]. Similarly, Zeng et al. [4] suggested that inhibition of the mammalian target of rapamycin (mTOR) with rapamycin suppressed kainate-induced spontaneous epilepsy. Further, epileptic status initiation with pilocarpine
$[5,6]$ and the effect of rapamycin on seizure development was reported [7]. Thus, mTOR pathway inhibitors are recognized as prospective antiepileptic compounds [8].

Oxidative stress with excessive reactive oxygen species (ROS) production is regarded as both involved in the mechanisms of kindled brain epileptisation [9-11] and a potential target for the action of antiepileptic drugs [12]. In addition, kindled seizures have been shown as an appropriate model for antiepileptic drug studies [13]. Simultaneously, the spectrum of mTOR blockers have antioxidant ef-

(C) 2021 Poshyvak O. B. et al. This is an open-access article distributed under the terms of the Creative Commons Attribution License, which permits unrestricted use, distribution, and reproduction in any medium, provided the original author and source are credited. 
fects $[14,15]$, while for axitinib, such effects are not consistent [16].

Aim. To prove the antioxidative and antiseizure effects of two drugs (axitinib and rapamycin) and their combination in PTZ-kindled rats.

\section{Materials and Methods}

Experimental animals. Experiments were performed on 300 male Wistar rats (two to four months old) with the initial body weight of 180-270 g. Animals were kept in standard conditions (constant temperature $23^{\circ} \mathrm{C}$, relative humidity $60 \%, 12 \mathrm{~h}$ dark/ light cycles; standard diet and tap water were given ad libitum) and were acclimatized to laboratory conditions at least seven days before the experiment. All experiments were carried out following the National Institutes of Health Guidelines for the care and use of laboratory animals and the European Council Directive on 24 November 1986 for Care and Use of Laboratory Animals (86/609/EEC). The experiments were approved by the Odesa National Medical University Bioethics Committee (UBC) (approval No. 3 dated 14/03/2016) before the study.

Epilepsy model. Kindled seizures were induced, as described previously [17]. PTZ (Sigma Aldrich, St. Louis, MO, USA) was given intraperitoneally (i.p.) daily at a dose of $35.0 \mathrm{mg} / \mathrm{kg}$ for 21 days. The severity of seizures was evaluated accordin to the following criteria: 0 , absence of symptoms of seizures; 1 , facial tremor and separate myoclonic jerks; 2, whole-body clonic seizures; 3 , clonic seizures of the whole body with rearings; 4 , generalized clonic-tonic seizures with rearings and falling; and 5 , repeated seizures as at stage 4 or lethal outcome as a result of seizures. Rats that demonstrated generalized seizures after both the $20^{\text {th }}$ and $21^{\text {st }} \mathrm{PTZ}$ injections were taken for further observations and evaluation effects of compounds.

Study design and experimental group. According to the study design, three main protocols were undertaken (Fig. 1).

Kindling model creation aimed to determine the axitinib and rapamycin median effective dose $\left(\mathrm{ED}_{50}\right)$, starting with 176 rats that demonstrated fully developed generalized seizures in response to the 20th and 21st PTZ administrations (Fig. 1, protocol A). Saline i.p. administration was used as a control group. At $24 \mathrm{~h}$ after the last injection, all rats of the control group (7 rats) and eight kindled rats were euthanized, and their brains were collected for biochemical analysis (Fig. 1, protocol $A$ ). The remaining kindled animals (169 rats) were randomly subdivided for ED50 determination of axitinib (86 rats) and rapamycin (83 rats) (Fig. 1, protocol B). Each group was randomly subdivided into subgroups based on graded doses of drugs. Treatment started within $24 \mathrm{~h}$ after the last PTZ administration and was performed for ten days. In $24 \mathrm{~h}$ after the 10th administration, two testing trials with PTZ (35.0 mg/kg, i.p.) were performed for $\mathrm{ED}_{50}$ determination. The number of rats treated with specific doses used in each trial is given in protocols $B$ and $C$.

The number of rats with the absence of generalized seizures was taken into account as a positive result of the treatment and it was used of $\mathrm{ED}_{50}$, and its error calculation. At $24 \mathrm{~h}$ after the PTZ administration, eight rats from each group treated with the maximal dosage of drugs were sacrificed for brain tissue biochemical analysis (Fig. 1, protocol $B$ ).

The combined effect of axitinib and rapamycin was investigated on another group of kindled rats (117 animals), which demonstrated generalized seizures as a response to the last two kindled PTZ injections (Fig. 1, protocol $C$ ). Animals were randomly assigned to subgroups aimed for three trials of rapamycin $\mathrm{ED}_{50}$ determination under conditions of axitinib $(2.0 \mathrm{mg} / \mathrm{kg}$, i.p.) treatment. Each group was treated daily with different dosages of rapamycin $\left(20,40,60\right.$, and $80 \%$ of its $\mathrm{ED}_{50}$ as determined in protocol $B$ ). Treatment started at $24 \mathrm{~h}$ after the last kindled PTZ administration and lasted ten days. At $24 \mathrm{~h}$ after the last drug administration, PTZ $\left(35.0 \mathrm{mg} / \mathrm{kg}\right.$, i.p.) was injected, and triple $\mathrm{ED}_{50}$ of rapamycin was determined. At $24 \mathrm{~h}$ after the moment of PTZ administration, eight rats treated with rapamycin $(0.56 \mathrm{mg} / \mathrm{kg}$, i.p.) were sacrificed, and their brains were collected for biochemical analysis.

With the aim to control for the effects of the dimethyl sulfoxide (DMSO) solvent, seven kindled rats were assigned additionally for ten days of DMSO ad-

\footnotetext{
Abbreviations: Akt - serine/threonine-specific protein kinase; BDNF- brain derived neurotrophic factor; DMSO - dimethyl sulfoxide; $\mathrm{ED}_{50}$ - median effective dose; $\mathrm{GSH}$ - reduced form of glutathione; MDA - malondialdehyde; mTOR mammalian target of rapamycin; PI3K - phosphoinositide 3-kinase (PI3K); PTZ - pentylenetetrazol; ROS - reactive oxygen species; SOD - superoxide dismutase; Trk - tyrosine kinase; TBA - thiobarbituric acid; VEGF - vascular endothelial growth factor.
} 

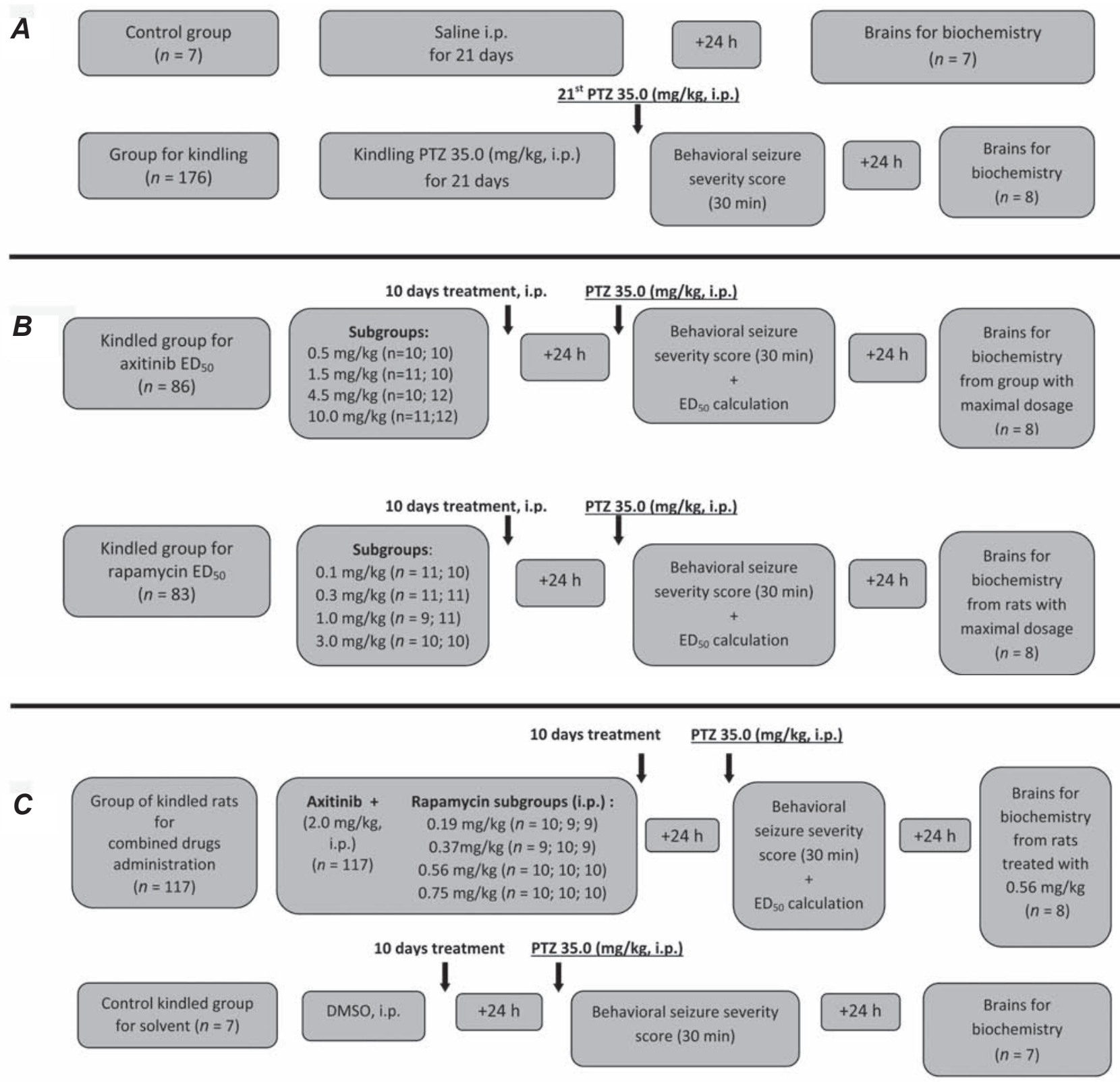

Fig. 1. Study design showing three protocols $(A, B, C)$. ED $D_{50}$ - median effective dose; i.p. - intraperitoneally; PTZ - pentylenetetrazol

ministration. After ten days of solvent administration and $24 \mathrm{~h}$ after the last PTZ injection $(35.0 \mathrm{mg} /$ $\mathrm{kg}$, i.p.), the induced seizure severity was estimated (Fig. 1, protocol $C$ ). At $24 \mathrm{~h}$ after the seizure test, brains were collected for biochemical analysis.

Biochemical investigations of oxidative stress. The animals were euthanized in protocols $A, B$, and $C$ (Fig. 1) using carbon dioxide, and the brains were removed and maintained over dry ice until the determination of oxidative tissue damage.
The tissue was homogenized in ice-cold $\left(4^{\circ} \mathrm{C}\right)$ $0.052 \mathrm{M}$ sodium phosphate buffer $(\mathrm{pH} 7.0)$ and $0.4 \mathrm{mM}$ EDTA to produce a $10 \%$ homogenate. The homogenate was centrifuged at $10,000 \times \mathrm{g}$ at $4^{\circ} \mathrm{C}$ for $30 \mathrm{~min}$, and the supernatant was separated for further measurements.

Lipid peroxidation was evaluated via measuring thiobarbituric acid (TBA) - active substances [18]. The spectrophotometry was performed at $530 \mathrm{~nm}$. The extinction coefficient of $1.56 \times 10^{5} \mathrm{~mol} / \mathrm{l}^{-1} \mathrm{~cm}^{-1}$ 
was used to determine the malondialdehyde (MDA) level, and results were expressed as nmol/mg of protein.

The superoxide dismutase activity (SOD, EC 1.15.1.1) was measured using the previously described method Kono [19]. Following this method, the homogenate's supernatant was incubated with nitroblue tetrazolium and hydroxylamine hydrochloride and monitored spectrophotometrically at $560 \mathrm{~nm}$. The percentage inhibition of the rate of nitroblue tetrazolium reduction to $50 \%$ of the maximum was then calculated as one unit of SOD activity. Results were expressed as IU/mg of protein.

The glutathione (GSH) level was estimated using the method described by Sedlak and Lindsay [20]. The assay used 5'5-dithiobis 2-nitrobenzoic acid that binds to the thiol group to give a colored compound detected at $412 \mathrm{~nm}$. The results were expressed in $\mu \mathrm{g} / \mathrm{mg}$ of protein.

Protein concentrations were determined by Lowry assay [21], using bovine serum albumin as the standard.

Administration of investigated compounds. In accordance with the study design in protocol $B$ (Fig. 1), axitinib (Sigma Aldrich, St. Louis, MO, USA) was administered in doses of $0.5,1.5,4.5$, $10.0 \mathrm{mg} / \mathrm{kg}$, i.p. and rapamycin (Pfizer, New Yourk, NY, USA) was administered in doses of $0.1,0.3,1.0$, $3.0 \mathrm{mg} / \mathrm{kg}$, i.p. Both compounds were dissolved in DMSO and delivered in $0.20-0.30 \mathrm{ml}$ at $60 \mathrm{~min}$ before PTZ administration. In protocol $C$, rapamycin was administered in dosages of 0.19, 0.37, 0.56 and $0.75 \mathrm{mg} / \mathrm{kg}$ combined with axitinib treatment at a dose of $2.0 \mathrm{mg} / \mathrm{kg}$, i.p. (Fig. 1).

Statistical analysis. The values of biochemical measurements were compared using one-way ANOVA and Tukey's honestly significant difference (HSD) post hoc test. Data were presented as a mean value (M) and standard error of the mean (SEM). $P$ values $<0.05$ were considered significant. To avoid the influence of outliers, only observations falling between the median \pm 3.0 standard deviations of the sample were included in the dataset. The ShapiroWilk test for normality was used. Calculation of $\mathrm{ED}_{50}$ and its error was performed using https:// www.aatbio.com/tools/ed50-calculator/. For comparison, the $\mathrm{ED}_{50}$ t-test for two means was used with a significance level $(\alpha)=0.05$. Linear regression was employed for dose-dependence studies. For statistical analysis, the program SPSS Statistics (IBM, New York, NY, USA) was used.

\section{Results and Discussion}

Behavioral characteristics of the seizures in kindled rats (protocol A). Seizures starting from the third to sixth injection and that were progressive in their development. The moment of kindling completion and inclusion of animals into the experimental group was recognized as generalized seizures induced with the two last PTZ administrations.

Effects of rapamycin and axitinib upon kindled seizures (protocol B). Treatment with axitinib at the lowest dosage $(0.5 \mathrm{mg} / \mathrm{kg}$, i.p.) prevented generalized seizures in one out of ten rats (10.0\%), while at the highest dosage $(10.0 \mathrm{mg} / \mathrm{kg}$, i.p.), seven out of 11 rats $(63.6 \%)$ did not manifest generalized seizure fits. The calculated $\mathrm{ED}_{50}$ of axitinib was $4.97 \pm 0.37 \mathrm{mg}$ (Fig. 2, A).

Administrations of rapamycin at the dosage of $0.1 \mathrm{mg} / \mathrm{kg}$, i.p., prevented seizures in one out of 11 rats $(9.1 \%)$. A ten times larger dosage $(1.0 \mathrm{mg} /$ $\mathrm{kg}$ ) prevented seizure fits in five out of nine $(55.6 \%)$, while the highest dosage $(3.0 \mathrm{mg} / \mathrm{kg}$, i.p.) effectively protected seven out of ten (70.0\%) rats from generalized seizures. The $\mathrm{ED}_{50}$ of rapamycin was $0.94 \pm 0.09 \mathrm{mg} / \mathrm{kg}$ (Fig. 2, B).

Searching for combined effects of drugs (protocol C). Rapamycin treatment in a dosage of $40 \%$ from the $\mathrm{ED}_{50}(0.37 \mathrm{mg} / \mathrm{kg})$ given under conditions of daily axitinib administration $\left(40 \%\right.$ of $\mathrm{ED}_{50}, 2.0 \mathrm{mg} /$ $\mathrm{kg}$ ) prevented generalized seizure fits in three out of nine (33.3\%) rats. A two times larger dosage (80\% of $\mathrm{ED}_{50}, 0.75 \mathrm{mg} / \mathrm{kg}$ ) effectively protected nine out of ten $(90.0 \%)$ rats from generalized seizures.

The $\mathrm{ED}_{50}$ of rapamycin under conditions of combined treatment with axitinib $\left(40 \%\right.$ of $\left.\mathrm{ED}_{50}\right)$ was $0.60 \pm 0.07 \mathrm{mg} / \mathrm{kg}$, which was $35.6 \%$ less when compared with the $\mathrm{ED}_{50}$ of solely administered rapamy$\operatorname{cin}(\mathrm{F}(1.4)=11.40, P<0.05)$.

Effects of rapamycin and axitinib upon oxidative stress in brain tissue. In brain tissue of kindled rats, the level of the oxidative stress marker MDA increased from $152.9 \pm 24.8$ up to $388.3 \pm 49.2 \mathrm{nmol} /$ $\mathrm{mg}$ of protein $(\mathrm{F}(1.14)=16.63, P<0.01)$. In axitinibtreated kindled rats, the MDA level also exceeded the control value by almost two times $(301.5 \pm 41.8 \mathrm{nmol} /$ $\mathrm{mg})(\mathrm{F}(1.14)=8.67, P<0.02)($ Fig. $3, A)$.

SOD activity dropped in kindled rats to $3.54 \pm 1.08 \mathrm{IU} / \mathrm{mg}$ of protein and was significantly lower when compared with the control value $(11.14 \pm 2.33 \mathrm{IU} / \mathrm{mg})(\mathrm{F}(1.14)=9.56, P<0.01)$. In rats treated with axitinib and rapamycin, SOD activity 

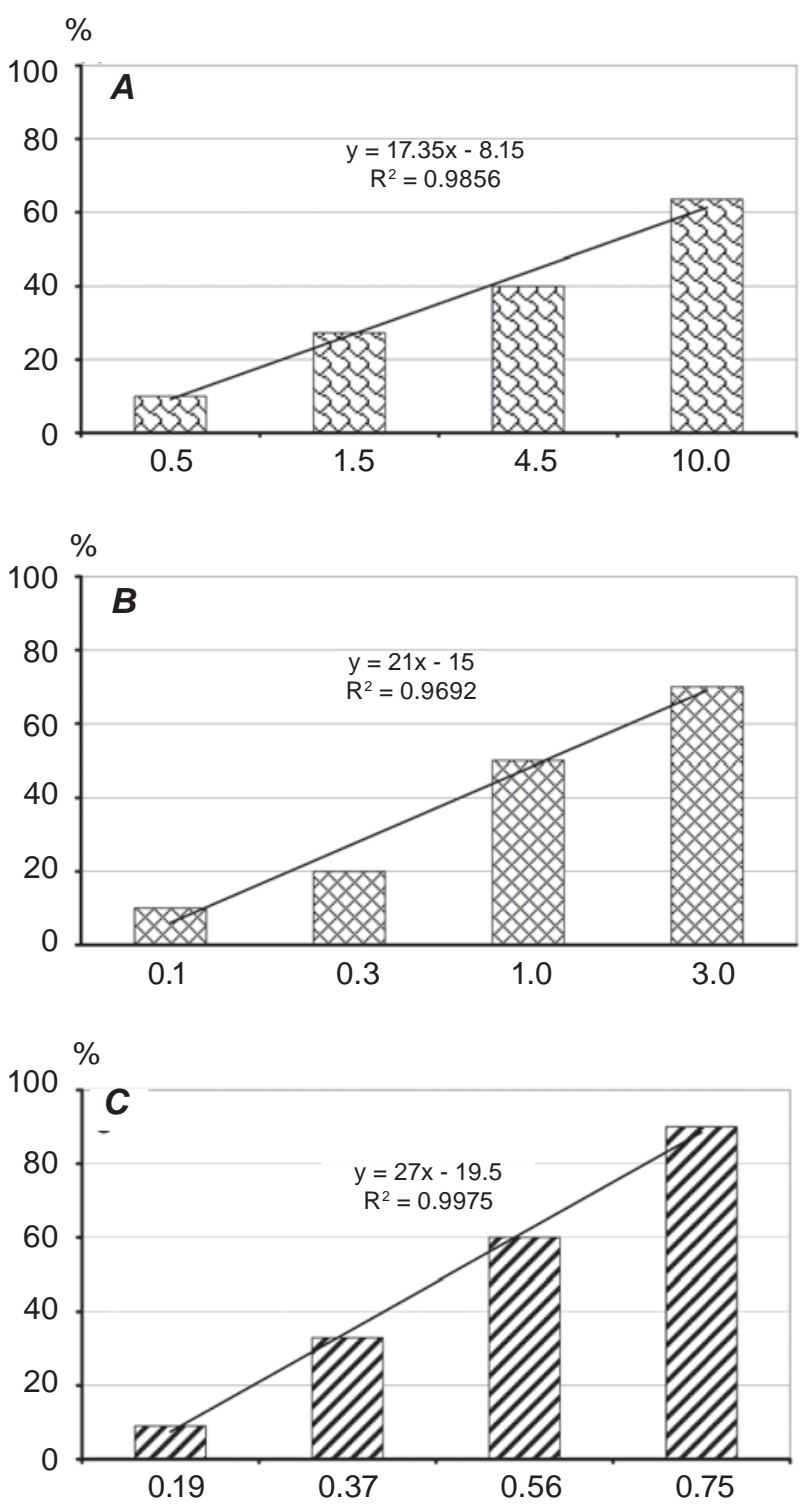

Fig. 2. Dose-dependent effects of axitinib and rapamycin upon kindled generalized seizures. A: effects of axitinib administered in different dosages (abscissa, $\mathrm{mg} / \mathrm{kg}$, i.p.) ( $(n=42)$; B: effects of rapamycin administered in different dosages (abscissa, $m g / k g$, i.p.) $(n=41)$; $C$ : effects of rapamycin administered in different dosages (abscissa, $\mathrm{mg} / \mathrm{kg}$, i.p.) delivered in combination with axitinib $(2.0 \mathrm{mg} / \mathrm{kg}$, i.p.) $(n=39)$. Ordinate in panels $\boldsymbol{A}, \boldsymbol{B}, \boldsymbol{C}$ : percentage of rats prevented from generalized seizures (the total number of rats in a given group was defined as $100 \%$ for that group)
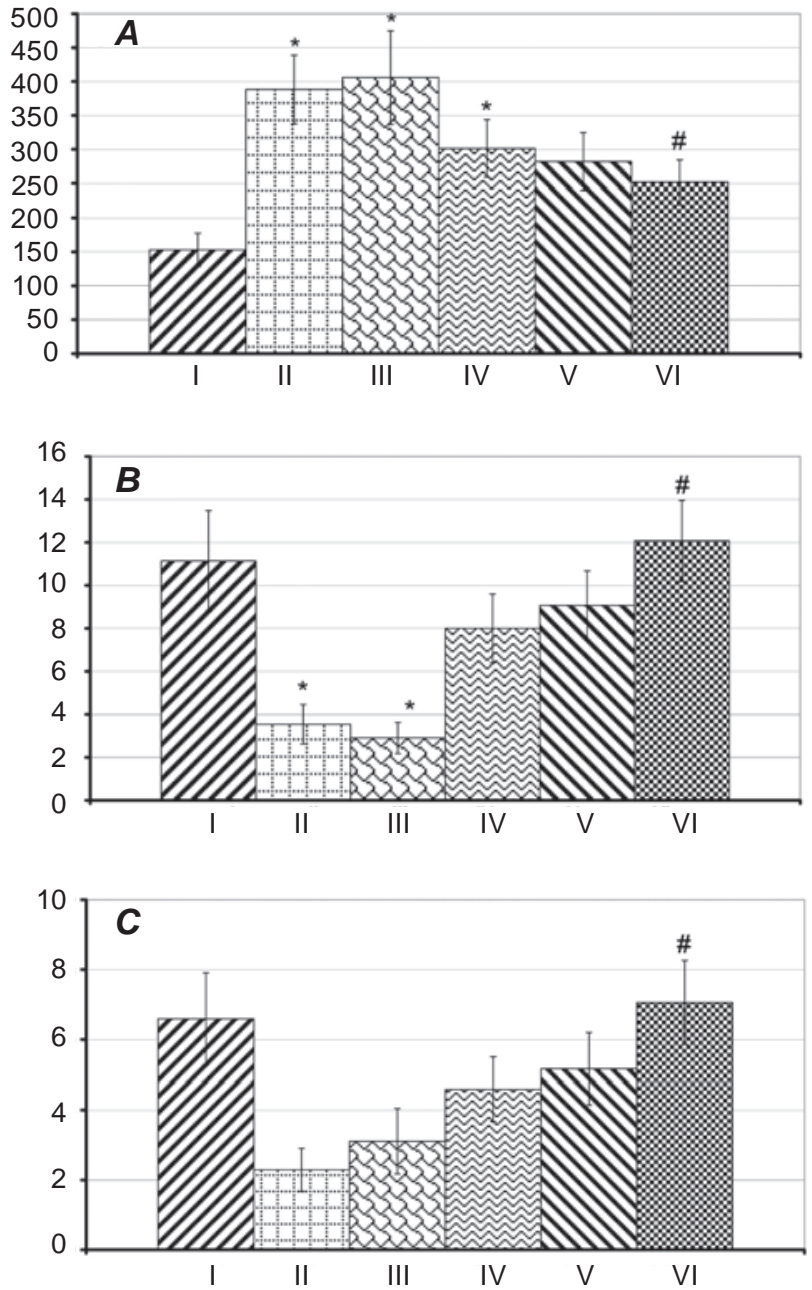

Fig. 3. Malondialdehyde (MDA) level (A), superoxide dismutase (SOD) activity (B), and glutathione $(G S H)$ level (C) in the brain of kindled rats under conditions of treatment with axitinib and rapamycin. Abbreviations: Abscissa: I - control (intact rats treated with saline - protocol A of Fig. 1) $(n=7)$; $I I-$ kindled rats $(n=8) ; I I I-k i n d l e d$ rats treated with the dimethyl sulfoxide (DMSO) solvent - protocol C of Fig. $1(n=8)$; IV-axitinib-treated kindled rats $(n=8) ; V$-rapamycin-treated kindled rats $(n=8) ; V I-$ combined treatment with axitinib and rapamycin $(n=8)$. Ordinates: Panel $\boldsymbol{A}-M D A$ level in nmol/mg of protein; Panel $\boldsymbol{B}-S O D$ activity in IU/mg of protein; Panel $\mathbf{C}-$ GSH level in $\mu \mathrm{g} / \mathrm{mg}$ of protein. ${ }^{*} P<0.05$ vs. I; ${ }^{\#} P<0.05$ vs. II (ANOVA + Tukey's test) 
$(11.90 \pm 1.86 \mathrm{IU} / \mathrm{mg})$ significantly exceeded that in the kindled rats $(\mathrm{F}(1.15)=17.05, P<0.01)($ Fig. $3, B)$.

In kindled rats treated with rapamycin and axitinib, the GSH level was $7.32 \pm 1.24 \mu \mathrm{g} / \mathrm{mg}$ of protein and significantly exceeded the value in non-treated kindled rats $(2.29 \pm 0.75 \mu \mathrm{g} / \mathrm{mg})(\mathrm{F}(1.15)=11.88$, $P<0.01$ ) (Fig. 3, C).

The data obtained in this study favored the dose-dependent effectiveness of axitinib and rapamycin against PTZ-kindled generalized seizure fits. Also, combined administration revealed a better effect against behavioral seizures and metabolic indices of oxidative stress. The increased effectiveness was proved with the significant reduction of the $\mathrm{ED}_{50}$ of rapamycin when combined with axitinib and a significant increase of SOD activity and GSH level compared with the corresponding values in kindled rats. In addition, the reduction of MDA observed in rats treated with both axitinib and rapamycin was more pronounced than in rats with separate drug administration.

Hence, the obtained data lead to the assumption that ROS production by itself represents the mechanism of kindled seizure development. Such an assumption is in concordance with Zhu et al. [11], who reported excessive MDA production and decreased enzymatic activities of SOD and glutathione peroxidase (GSH-PX) in the hippocampus in fully PTZkindled mice. Suppression of ROS production might also underlie or significantly contribute to the combined effect of the investigated drugs' antiseizure action. Such an assumption corresponds with data on reducing MDA, SOD, and GSH-PX caused by rapamycin in the model of testicular torsion-detorsion injury [22]. Antioxidant effects caused by rapamycin/mTOR blockade have been shown under different pathologic conditions [23, 24].

For axitinib, a more subtle antioxidant action, if any, might be assumed as far as oxidative stressmediated genotoxic effects are recognized as the primary mechanism of antitumor activity, realized in concordance with the targeting of receptors of vascular endothelial growth factor (VEGFR) 1-3 [25].
Besides VEGFR-targeted effects also include oxidative DNA damage, leading to mitotic catastrophe and a cellular senescence program. Nevertheless, it was shown that the analogous inhibitor of tyrosine kinase B, sunitinib, might even act as an antioxidant by ameliorating lipid peroxidation and increasing the GSH level in cisplatin-treated mice [25].

Hence, considering that the expression of brain derived neurotrophic factor (BDNF) is linked with ROS production, the presence of a functional interaction between mTOR and BDNF-Trk $[26,27]$ creates the basis for the synergy of the antiseizure action of rapamycin and axitinib. Our study findings suggest the combined usage of these two drugs for the blockade of two different kinase signaling pathways - PI3K-Akt-mTOR and BDNF-TrkB - to improve the effectiveness of epilepsy treatment.

Conclusions. The study data favor the role played by ROS production in brain tissue for the development of PTZ-induced kindled seizures. The increased effectiveness of axitinib and rapamycin regarding the reduction of oxidative stress manifestations might contribute to their improved seizure control.

Conflict of interest. Authors have completed the Unified Conflicts of Interest form at http://ukrbiochemjournal.org/wp-content/uploads/2018/12/ coi_disclosure.pdf and declare no conflict of interest.

Funding. The research was carried out within the framework of the research projects "Epigenetic mechanisms of realization of the action of physical factors on the structures of the brain and homeostasis" (Registration number № 0116u008928), "Influence of physical factors on the brain and immunological reactivity" (Registration number №0112u004061.

Acknowledgment. We thank Cedars-Sinai Medical Center's International Research and Innovation in Medicine Program and the Association for Regional Cooperation in the Fields of Health, Science and Technology (RECOOP HST Association) for their support. 
ПРИГНІЧЕННЯ ОКСИДАТИВНОГО

СТРЕСУ ПОСИЛЮС

ПРОТИСУДОМНИЙ ЕФЕКТ

АКСИТИНІБУ ТА РАПАМІЦИНУ

ЗА ПЕНТИЛЕНТЕТРАЗОЛІНДУ КОВАНОГО КІНДЛІНГУ

О. Б. Пошивак ${ }^{1 凶}$, О. Р. Піняжко ${ }^{1,2}$, Л. С. Годлевський

${ }^{1}$ Львівський національний медичний університет імені Данила Галицького, Львів, Україна;

${ }^{2}$ Університет інформаційних технологій та менеджменту, Польща;

${ }^{3}$ Одеський національний медичний університет, Україна;

凶e-mail: olesya.poshyvak@gmail.com

Рапаміцин i акситиніб блокують різні кінази у PI3K-Akt-mTOR та у BDNF-TrkB сигнальних шляхах відповідно. Обидва препарати мають протисудомну і антиоксидантну дію, що обгрунтовує вивчення їх комбінованої дії на моделі хронічної епілепсії. Метою роботи було дослідити ефект комбінованої дії цих препаратів на пентилентетразол(PTZ)-індуковані судомні напади та оксидативний стрес. Дослідження проводили на 300 щурах-самцях лінії Wistar, яким щодня вводили епилептоген PTZ (35,0 мг/кг, в/ч). Визначали рівень малонового діальдегіду (MDA), активність супероксиддисмутази (SOD) i рівень глутатіону (GSH) в тканинах мозку щурів із індукованим кіндлінгом до і після лікування препаратами. Аналіз протисудомної та антиоксидантної дії проводили за оцінкою середньоефективних доз $\left(\mathrm{ED}_{50}\right)$ рапаміцину та акситинібу за їх комбінованого введення з використанням градієнта доз $\mathrm{ED}_{50}$ для кожного препарату. Встановлено, що $\mathrm{ED}_{50}$ для рапаміціна $\mathrm{i}$ акситиніба складала 0,93 і 4,97 мг/кг, відповідно. $\mathrm{ED}_{50}$ для рапаміціна за комбінованого застосування 3 акситинібом (2,0 мг/кг) становила 0,60 мг/кг, що на $35,6 \%$ нижче порівняно з $\mathrm{ED}_{50}$ окремо введеного препарату $(P<0,05)$. У тканинах мозку кіндлінгових щурів рівень MDA збільшився з $152,9 \pm 24,8$ до $388,3 \pm 49,2$ нмоль/ мг протеїну $(P<0,05)$, в той час як активність SOD знизилася з $11,14 \pm 2,33$ до $3,54 \pm 1,08 \mathrm{MO} /$ мг протеїну $(P<0,05)$. Комбіноване лікування рапаміцином $(0,56 \mathrm{мг} / \kappa г$, в/ч) та акситинібом $(2,0$ мг/кг, в/ч) призводило до значного підвищення активності SOD $(11,09 \pm 1,86 \mathrm{MO} / \mathrm{Mг})$ i рівня GSH (7,32 $\pm 1,34$ мкг/мг) порівняно 3 показниками кіндлінгових щурів $(P<0,05)$. Встановлено, що комбінована терапія акситинібом та рапаміцином має протиепілептичний і антиоксидантний ефект за PTZ-індукованого кіндлінгу в щурів.

К л ю чов і слов а: судоми, пентиленететразол-індукований кіндлінг, оксидативний стрес, акситиніб, рапаміцин.

\section{References}

1. Fisher RS, Acevedo C, Arzimanoglou A, Bogacz A, Cross JH, Elger CE, Engel JJr, Forsgren L, French JA, Glynn M, DC Hesdorffer, Lee BI, Mathern GW, Moshé SL, Perucca E, Scheffer IE, Tomson T, Watanabe M, Wiebe S. ILAE official report: a practical clinical definition of epilepsy. Epilepsia. 2014; 55(4): 475-482.

2. Chubach VS, Muratova TN, Myronenko SI, Godlevsky LS. Antiepileptic effects of axitinib on pentylenetetrazol- induced kindling in rats. Epilepsia. 2015; 56 (Suppl 1): 0142.

3. Liu J, Schenker M, Ghiasvand S, Berdichevsky Y. Kinase inhibitors with antiepileptic properties identified with a novel in vitro screening platform. Int J Mol Sci. 2019; 20(10): 2502.

4. Zeng LH, Rensing NR, Wong M. The mammalian target of rapamycin signaling pathway mediates epileptogenesis in a model of temporal lobe epilepsy. J Neurosci. 2009; 29(21): 6964-6972.

5. Buckmaster PS, Ingram EA, Wen X. Inhibition of the mammalian target of rapamycin signaling pathway suppresses dentate granule cell axon sprouting in a rodent model of temporal lobe epilepsy. J Neurosci. 2009; 29(25): 8259-8269.

6. Huang X, Zhang H, Yang J, Wu J, McMahon J, Lin Y, Cao Z, Gruenthal M, Huang Y. Pharmacological inhibition of the mammalian target of rapamycin pathway suppresses acquired epilepsy. Neurobiol Dis. 2010; 40(1): 193-199.

7. van Vliet EA, Forte G, Holtman L, den Burger JCG, Sinjewel A, de Vries HE, Aronica E, Gorter JA. Inhibition of mammalian target of rapamycin reduces epileptogenesis and blood-brain barrier leakage but not microglia activation. Epilepsia. 2012; 53(7): 1254-1263.

8. Wang F, Chen F, Wang G, Wei S, Fang F, Kang D, Lin Y. Rapamycin provides anti-epileptogenic 
effect in a rat model of post-traumatic epilepsy via deactivation of mTOR signaling pathway. Exp Ther Med. 2018; 15(6): 4763-4770.

9. Godlevsky LS, Shandra AA, Oleinik AA, Vastyanov RS, Kostyushov VV, Timchishin OL. TNF-alpha in cerebral cortex and cerebellum is affected by amygdalar kindling but not by stimulation of cerebellum. Pol J Pharmacol. 2002; 54(6): 655-660.

10. Jesus M, Martins APJ, Gallardo E, Silvestre S. Diosgenin: Recent Highlights on Pharmacology and Analytical Methodology. J Anal Methods Chem. 2016; 2016: 4156293.

11. Zhu X, Dong J, Shen K, Bai Y, Zhang Y, Lv X, Chao J, Yao H. NMDA receptor NR2B subunits contribute to PTZ-kindling-induced hippocampal astrocytosis and oxidative stress. Brain Res Bull. 2015; 114: 70-78.

12. Geronzi U, Lotti F, Grosso S. Oxidative stress in epilepsy. Expert Rev Neurother. 2018; 18(5): 427-434.

13. Shandra AA, Mazarati AM, Godlevsky LS, Vastyanov RS. Chemical kindling: implications for antiepileptic drugs - sensitive and resistant epilepsy models. Epilepsia. 1996; 37(3): 269-274.

14. Jiang J, Jiang J, Zuo Y, Gu Z. Rapamycin protects the mitochondria against oxidative stress and apoptosis in a rat model of Parkinson's disease. Int J Mol Med. 2013; 31(4): 825-832.

15. Singh AK, Singh S, Garg G, Rizvi SI. Rapamycin alleviates oxidative stress-induced damage in rat erythrocytes. Biochem Cell Biol. 2016; 94(5): 471-479.

16. Mihajlovic M, Ivkovic B, Jancic-Stojanovic B, Zeljkovic A, Spasojevic-Kalimanovska V, Kotur-Stevuljevic J, Vujanovic D. Modulation of oxidative stress/antioxidative defence in human serum treated by four different tyrosine kinase inhibitors. Anticancer Drugs. 2020; 31(9): 942949.

17. Godlevsky LS, Muratova TN, Kresyun NV, van Luijtelaar G, Coenen AML. Anxiolytic and antidepressive effects of electric stimulation of the paleocerebellar cortex in pentylenetetrazol kindled rats. Acta Neurobiol Exp (Wars). 2014; 74(4): 456-464.

18. Ohkawa H, Ohishi N, Yagi K. Assay for lipid peroxides in animal tissues by thiobarbituric acid reaction. Anal Biochem. 1979; 95(2): 351358.
19. Kono Y. Generation of superoxide radical during autoxidation of hydroxylamine and an assay for superoxide dismutase. Arch Biochem Biophys. 1978; 186(1): 189-195.

20. Sedlak J, Lindsay RH. Estimation of total, protein-bound, and nonprotein sulfhydryl groups in tissue with Ellman's reagent. Anal Biochem. 1968; 25(1): 192-205.

21. Lorwy $\mathrm{OH}$, Rosenbrough NJ, Farr AL, Randall RJ. Protein measurement with the Folin phenol reagent. J Biol Chem. 1951; 193(1): 265275.

22. Ghasemnejad-Berenji M, Ghazi-Khansari M, Pashapour S, Jafari A, Yazdani I, GhasemnejadBerenji H, Saeedi Saravi SS, Sadeghpour S, Nobakht M, Abdollahi A, Mohajer Ansari J, Dehpour AR. Synergistic effect of rapamycin and metformin against germ cell apoptosis and oxidative stress after testicular torsion/detorsioninduced ischemia/reperfusion in rats. Biomed Pharmacother. 2018; 105: 645-651.

23. Suyani E, Derici UB, Sahin T, Ofluoglu E, Pasaoglu H, Erdem O, Barit G, Reis KA, Erten Y, Arinsoy T, Sindel S. Effects of everolimus on cytokines, oxidative stress, and renal histology in ischemia-reperfusion injury of the kidney. Ren Fail. 2009; 31(8): 698-703.

24. Rosing K, Fobker M, Kannenberg F, Gunia S, Dell'Aquila AM, Kwiecien R, Stypmann J, Nofer JR. Everolimus therapy is associated with reduced lipoprotein-associated phospholipase A2 (Lp-Pla2) activity and oxidative stress in heart transplant recipients. Atherosclerosis. 2013; 230(1): 164-170.

25. Teppo HR, Soini Y, Karihtala P. Reactive Oxygen Species-Mediated Mechanisms of Action of Targeted Cancer Therapy. Oxid Med Cell Longev. 2017; 2017: 1485283.

26. Fahnestock M, Nicolini C. Bridging the gap between genes and behavior: Brain-derived neurotrophic factor and the mTOR pathway in idiopathic autism. Autism Open Access. 2015; 5: 2.

27. Moya-Alvarado G, Bronfman FC. BDNF/ TrkB mediates long-distance dendritic growth by activating CREB/PI3K-mTOR-dependent translation in neuronal cell bodies. bioRxiv. 2020.08.22.262923. 